\title{
A scientific note on the specific optical rotation of three honey types from Bulgaria
}

\author{
Dinko DinKOV* \\ Faculty of Veterinary Medicine, Trakia University, 6000 Stara Zagora, Bulgaria \\ (Received 12 February 2002; revised 25 November 2002; accepted 27 November 2002) \\ honey / Robinia sp. / multifloral / honeydew / specific optical rotation / Bulgaria
}

Honey has the property to rotate the polarization plane of polarized light. This depends largely on types and relative proportions of sugars in honey. Each sugar has a specific effect, and the total optical rotation is dependent on concentration. Floral honeys are laevorotary and honeydew (or adulterated floral) honeys are usually dextrorotary. This is a consequence of the normal preponderance in honey of fructose, which has a negative specific rotation, $\left([\alpha]_{D}{ }^{20}=-92.4^{\circ}\right)$ over glucose $\left([\alpha]_{D}{ }^{20}=\right.$ $\left.+52.7^{\circ}\right)($ Battaglini and Bosi, 1973; Ivanov, 1986)

The measurement of specific rotation is currently used in Greece, Italy and UK to distinguish blossom and honeydew honeys. In Italy, blossom honeys have negative values of optical rotation, while honeydew honeys have positive ones (Kirkwood et al., 1960; Kirkwood et al., 1961; Sacchi and Bosi, 1963; Battaglini and Bosi, 1973; Piazza et al., 1991; Persano Oddo et al., 1995, 1997). Honeydew honeys are usually somewhat lower in fructose content and contain melezitose $\left(\left([\alpha]_{\mathrm{D}}{ }^{20}=+88.2^{\circ}\right)\right.$ or erlose $\left(\left([\alpha]_{\mathrm{D}}{ }^{20}=+121.8^{\circ}\right)\right.$ (Ivanov, 1986).

The aim of the study was to apply the method for determination of the specific optical rotation of bee honey according to the Harmonized Methods of the European Honey Commission (Bogdanov et al., 1997) for multifloral, honeydew and Robinia sp. honeys from Bulgaria. The results of the Bulgarian "off-hand method" (Ivanov, 1986) are different from those obtained from the method used by the European Honey Commission (Bogdanov et al., 1997). For that purpose a comparison of optical measurements of Bulgarian honeys from different origins was carried out with the harmonised method of the European Honey Commission.
The specific optical rotation $\left([\alpha]_{\mathrm{D}}{ }^{20}\right)$, was determined in 29 honeys (Robinia sp. $\mathrm{n}=10$, multifloral $\mathrm{n}=10$, honeydew $\mathrm{n}=9$ ), produced in 2000, from various regions and different phytogeographical areas in Bulgaria. The specific optical rotation was evaluated by the method of the European Honey Commission (Bogdanov et al., 1997)

The botanical origin of the samples (Tab. I) was established by their melissopalynological, organoleptic, physical and chemical characteristics (Louveaux et al., 1978; Persano Oddo et al., 1995).

The results from the study on the specific optical rotation, are presented in Table I. It was estimated that the specific optical rotation of the Robinia honeys was (-) $17.0 \pm 1.2$, which was similar to previously reported values (Piazza et al., 1991; Persano Oddo et al., 1997). The average value of the multifloral honeys was (-) $14.8 \pm 4.9$, which was similar of the values of multifloral honeys found by Sacchi and Bosi (1963) and to those found in Robinia honeys.

The values of the specific optical rotation of the Bulgarian honeydew honeys were positive (4.2 \pm 1.3), which is consistent with other results (Kirkwood et al., 1960; Kirkwood et al., 1961; Sacchi and Bosi, 1963; Battaglini and Bosi, 1973; Persano Oddo et al., 1995). However these values were lower than those found in Italian honeydew honeys, which varied from 13.6 to 16.6.

Note scientifique sur la rotation optique spécifique de trois types de miels de Bulgarie.

Eine wissenschaftliche Notiz zur spezifischen optischen Drehung von drei Honigsorten aus Bulgarien.

\footnotetext{
* Correspondence and reprints

E-mail: dinkodinkov@yahoo.com
} 
Table I. Modification of analytical characteristics of honeys according to their origin (mean \pm SD).

\begin{tabular}{lcccc}
\hline Analytical criterion & $\begin{array}{c}\text { Robinia } \text { sp. } \\
\mathrm{n}=10\end{array}$ & $\begin{array}{c}\text { Multifloral } \\
\mathrm{n}=10\end{array}$ & $\begin{array}{c}\text { Honeydew } \\
\mathrm{n}=9\end{array}$ & $P$ \\
\hline Specific rotation $[\alpha]_{\mathrm{D}}{ }^{20(1)}$ & $(-) 17.0 \pm 1.2^{\mathrm{a}}$ & $(-) 14.8 \pm 4.9^{\mathrm{a}}$ & $(+) 4.2 \pm 1.3^{\mathrm{b}}$ & $<0.01$ \\
Water content $(\%)$ & $16.7 \pm 0.9^{\mathrm{a}}$ & $16.3 \pm 0.7^{\mathrm{a}}$ & $17.2 \pm 1.2^{\mathrm{a}}$ & - \\
${\text { Invertase content }\left(\mathrm{IN}^{(2)}\right)}^{3.8 \pm 2.4^{\mathrm{a}}}$ & $11.0 \pm 3.26^{\mathrm{a}}$ & $30.48 \pm 5.92^{\mathrm{b}}$ & $<0.01$ \\
$\mathrm{HMF}^{(3)}\left(\mathrm{mg} \cdot \mathrm{kg}^{-1}\right)$ & $1.9 \pm 1.4^{\mathrm{a}}$ & $2.6 \pm 1.3^{\mathrm{a}}$ & $2.7 \pm 2.0^{\mathrm{a}}$ & - \\
$\begin{array}{l}\text { Electrical conductivity } \\
\left(\mathrm{mS} \cdot \mathrm{sm}^{-1}\right)^{(4)}\end{array}$ & $0.1 \pm 0.1^{\mathrm{a}}$ & $0.5 \pm 0.3^{\mathrm{b}}$ & $1.1 \pm 0.2^{\mathrm{b}}$ & $<0.05$ \\
Proline cont. $\left(\mathrm{mg} \cdot \mathrm{kg}^{-1}\right)$ & $213.4 \pm 172.3^{\mathrm{a}}$ & $267.2 \pm 23.7^{\mathrm{a}}$ & $564.5 \pm 23.3^{\mathrm{b}}$ & $<0.01$ \\
Pollen grains & Above $30 \%$ pollen & Different pollen grains & $\mathrm{HDE} / \mathrm{P}^{(5)} \geq 3$ & - \\
\hline
\end{tabular}

Data bearing different letters are significantly different according to one way ANOVAs followed by Tukey test for multiple comparison of means.

${ }^{(1)}[\alpha]_{D}{ }^{20}$ - specific angular rotation (Bogdanov et al., 1997);

${ }^{(2)}$ IN - invertase number (Bogdanov et al., 1997);

${ }^{(3)} \mathrm{HMF}$ - content of hydroxymethilfurfural (Bogdanov et al., 1997);

${ }^{(4)} \mathrm{mS} \cdot \mathrm{sm}^{-1}$ - milli simens per cantimetre (Bogdanov et al., 1997);

${ }^{(5)} \mathrm{HDE} / \mathrm{P}$ - Honeydew elements/pollen grains (Persano Oddo et al., 1997).

\section{REFERENCES}

Battaglini M., Bosi G. (1973) Caratterizzatione chemico-fisica dei mieli monoflora sulla base dello spettro glucidico e del potere rotatorio specifico, Sci. Technol. Alim. 3, 217-221.

Bogdanov S., Lüllman C., Martin P. (1997) Harmonized methods of the European Honey Commission, Apidologie extra issue, 58-59.

Ivanov Tz. (1986) Quality, standartisation and qualifycation of Honey products, Survey, Agricultural Academic, Sofia, Bulgaria, pp. 731 .

Kirkwood K.C., Mitchell T.J., Smith D. (1960) An examination of the Occurrence of Honeydew in Honey. Part I, Analyst 85.

Kirkwood K.C., Mitchell T.J., Rose I.C. (1961) An examination of the Occurrence of Honeydew in Honey. Part II, Analyst 86.
Louveaux J., Maurizio A., Vorwohl G. (1978) Methods of Melissopalynology, Bee World 59, 139-157.

Persano Oddo L., Piazza M.G., Sabatini A.G., Accorti M. (1995) Characterization of unifloral honeys, Apidologie 26, 453-465.

Persano Oddo L., Sabatini A.G., Accorti M., Colombo R., Marcazzan G.L., Piana M.L., Piazza M.G., Pulcini P. (1997), I mieli uniflorali italiani - Nuove schede di caratterizzatione, Ministero delle Politiche Agricole e Forestali, pp. 30-31, 64.

Piazza M.G., Accorti M., Persano Oddo L. (1991) Electrical conductivity, ash, colour, and specific rotatory power in Italian unifloral honeys, Apicoltura 7, 51-63.

Sacchi R., Bosi G. (1963) Variabilità nel contenuto di ceneri, ferro, anidride fosforica, calcio, proteine e della "rotatione specifica" in mieli italiani, L'Apicoltore d'Italia 89, 30. 